\title{
PROBLEMS OF EARTHEN PRODUCTS IN PRESENT MARKET: A STUDY OF BENGAL POTTERY
}

\author{
KANDARPA KANTI HAZRA ${ }^{1} \&$ Dr. ARUP BARMAN ${ }^{2}$ \\ ${ }^{I}$ Scholar, Department of Business Administration, Assam University, Silchar, India \\ ${ }^{2}$ Professor, Department of Business Administration, Assam University, Silchar, Assam, India
}

\begin{abstract}
From the prehistoric times the cultural evolution is an ever-going eternal process. The various metallic utensils as well as potteries were a part of that ever-developing evolutionary process. Human beings according to the needs and necessities kept on changing their modes of livelihoods. In west Bengal also one has evidenced the various art, crafts, utensils of daily household elements from the different ages of the historical developments. Craftsmanship and culture are indistinguishable attachments of development. It represents the practice, religious beliefs, and indicates spiritual upliftment and represents societal system of that period. Earth pottery is an ancient expertise in India. The specialty of Clay Pottery is that it developed alongside with the Civilization.
\end{abstract}

KEYWORDS: Craft, Clay Doll, Heritage, Problems, Art \& Market

Received: Jun 08, 2020; Accepted: Jun 28, 2020; Published: Jul 07, 2020; Paper Id.: IJMPERDJUN2020225

\section{INTRODUCTION}

The traditional folk art of Indian Clay Pottery, particularly of Bengal, is considered exceptional and best in the world. Indian are reflecting the fusion of Social and religions conditions prevalent during the contemporary period when they were made. During that period of time when India was under the British rule, started to spread the art by their influence on common people as well they influenced every sector of the society and their concepts of realistic art exert an influence on these artists also. On the one hand the modern and realistic concepts of art and the other hand the commonplace simple art form of native Bengal both provided impact on the artifacts of that era. Though the craftsman or potters of that period didn't have immense name and fame but it's the Britishers only who propagated the clay art forms in a worldwide platform. The earthen pottery architectures have always been in vogue since the early ages of human civilizations. Evidences of such architectural exploits are excavated from the various parts of the Indian sub-continent.

\section{BACKGROUND OF THE STUDY}

Though it's not very much evident that terracotta potteries and architectures being available in the early stone age still archaeologists are of the opinion that in 1960 renowned archaeologist James Mellart recovered various clay potteries from Anatlia Valley of Turkey which he claimed to be ten thousand years old. Again, in Thailand evidence of these clay potteries are also available which are considered to be 6800 years old, even in Baluchistan also well decorated clay potteries are available of 4000 B.C. So, these architectures and potteries help us a lot to have a deep insight of the people of our early ages. The hidden stories of their lives and their livelihood, their habitats, their untiring efforts of adjust extreme nature, weather and finally they also reveal various minute distinctions about the period in which they flouris 


\section{REVIEW OF LITERATURE}

P. K. Mandal (1987) in his Interpretations of from Tamralipta provides detailed study on the clay specimens preserved in the Tamralipta Museum and Research Centre, Tamluk and also some of the private collections. Apart from discussing the manufacturing technique and themes he gives a detailed trait wise classification of the specimens in different cultural periods in tabular format. Sharmi Chakraborty (2000), in her doctoral thesis Chandraketugarh: A Cultural and Archaeological Study, gave a detailed description of the earthen figurines and plaques yielded from Chandraketugarh and housed in different museums and private collections and also classified them. Arputha Rani Sengupta (2005) has dealt with the terracotta temples of Bishnupur in Bankura district of West Bengal. By tracing the origin of the terracotta temples, she demonstrated the cult and religious value of the terracotta art in ancient times and in present context. She described various techniques of making terracotta plaques. By studying the contents of the terracotta reliefs from the temples she showed that the variations in the plaques covering the walls, vaults, domes and archways were meant to glorify the gods and the Malla kings of Bishnupur. More recently, Sengupta, Roy Chowdhury and Chakraborty in 2007 have published a comprehensive catalogue with detailed description and photographs of clay materials preserved in State Archaeological Museum, West Bengal, discovered mostly from the site of Chandraketugarh. Several specimens from Harinarayanpur, Mangalkot, Deulpota, Tamluk, Bangarh, Natsal, Pandu RajarDhibi, Farakka, Tilpi, etc. have also been covered in their book

\section{Various Features of the Craft}

In the Yajur Veda also the mention of the term "kulal" gives us an impression these potters were present during that period of the vedic age, as "kulal" refers to the society of potters. Next shift in our focus is on the Indus Valley civilization. When an intensive study was conducted where it was quite evident that clay utensils, jewellery, and various potteries were extensively used during the Indus Valley civilizations. So it's no more a hidden fact that terracotta architecture developed and flourished in the Indian sub-continent only. It flourished almost around five thousand years ago. During that period of time it's the clay art which played a major role in making various household items and as well as the earthen dolls and toys. Through various extensive archaeological site, the historical proof of that period not only give us a deep knowledge about their household life and social life but also various useful information about that period of time. Various figures and calligraphy on the earthen pots, toys and the dices provided a vivid knowledge of the era.

\section{Present Status of the Craft}

In recent times also from the village named Chandraketughar of the south 24 parganas of Westbengal historians have excavated the the remains of earthen pots and potteries and crockery and other samples of objects made if clay which gave a detail overview of the Khorosthi manuscript. An earthen pot of Kushan Age has an inscription written on it which in its contemporary language of that period which reads that 'one should plant seeds'. Besides that in a earthen tablet of the Shunga age we witness an inscription of a date tree from which the date juices are collected by some local method of juice collection. It's evident that during that time these activities were quite common during that. Society

\section{Source of Data}

The source of data is both primary and secondary in nature. The method of the collection of data is mainly through survey. An investigation through observation and personal interview with structure questionnaire used for appropriate collection for the necessary information of the study. Data collection from the contemporary clay doll makers and people interested in ethnographic experience, has also been approached, such as- 
- Direct observation and observation in a way involving participation.

- Interviewing pragmatically in non-structured and /or semi structured format

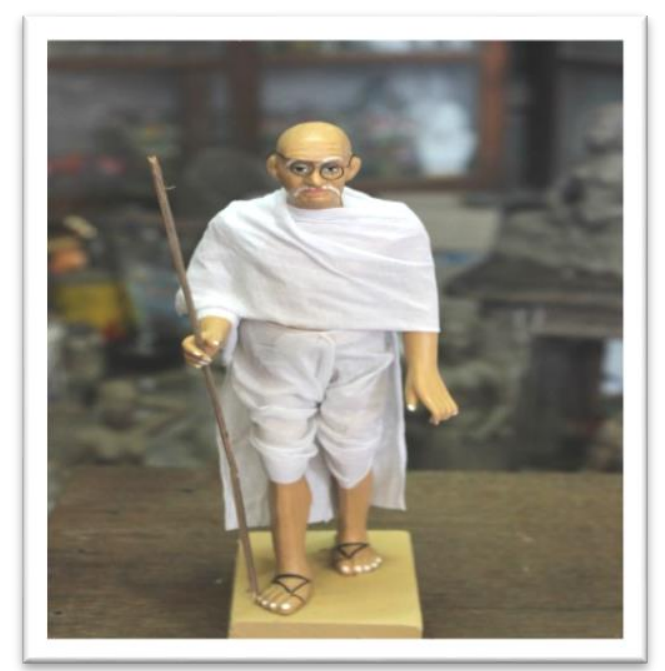

Figure 1: Gandhi Doll Picture of Ghurni.

\section{Sampling Technique}

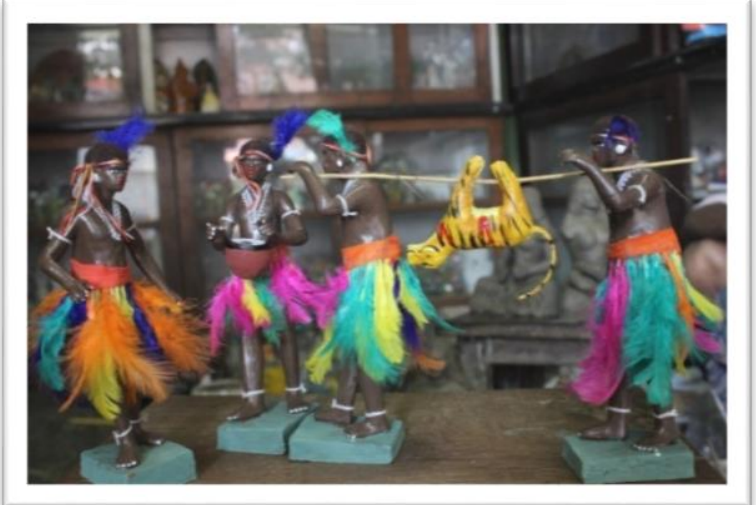

Figure 2: This Genre Originally Represent the Ancient Doll Making of the Nadia.

In simpler terms, the sample corresponds to the population are the vital characteristics of research conclusion. In the present study, first of all, stratified sampling technique has been used for selection of doll making cluster and associated population, and then convenient interview process has been conducted for selection of the major cluster of artisan from the non-reluctant conscious respondent.

\section{CONCLUSIONS}

A lot much study has been conducted about Bengal doll. Numbers of articles, government reports are also available, sometime in every year a report or documentary was made by enthusiast about why this ancient enriched craft is now in miserable conditions? What Government should do for them, is government aids is sufficient and satisfactory? In support of all those document a lot many picture, data, survey report also included, and sometimes suggestion also given in respect of the problems that was highlighted. But interesting thing is that dolls remains same, as it was silent,humble,self obsessed and as appealing as before. Government has already taken some step to boost up the industry. I am not advocating the govern 
steps are sufficient or the government has done all his duties, and there also a fact of discrimination about receiving the government facilities, perhaps there is some grievances is present.

But criticizing government or not receiving proper government cooperation cannot be the only reasons of degradation of that craft. We all know the effect of change or action at the need of the time is sometime frutful,as the saying goes that change is the only constant. Those who able to shift their craft with changing demand of world and most importantly market, excelling in their business

\section{REFERENCES}

1. Council of Handicrafts Development Corporation. (2014). Flexible Fish-Brass \& Wood. Retrieved December 24, 2014, from http://www.cohands.in/handmadepages/pdf.204/pdf

2. Council of Handicrafts Development Corporations, Ministry of Textiles, Government of India. (n.d.). FLEXIBLE FISHBRASS AND WOOD. Retrieved June 27, 2016, from http://www.cohands.in/handmadepages/pdf/204.pdf

3. Sengupta, J.(2011).Indian Handicraft and Handloom Workers Life and Working Conditions in Villages-A Brief Survey In Organization Research Foundation Paper Series, New Delhi.

4. Ray, Amita, and Samir K. Mukherjee. (1992). "Excavation at Mangalkot.” Pratna Samiksha 1: 107-134.

5. ICRIER (Indian Council for Research in International Economic Relations) study (1993).

6. Sengupta, J.(2011).Indian Handicraft and Handloom Workers Life and Working Conditions in Villages-A Brief Survey In Organization Research Foundation Paper Series, New Delhi. 